\title{
Carl Whiting Bishop
}

W ITH the death of Carl Whiting Bishop, America's veteran Far Eastern archaeologist, the field of Oriental studies has lost one of its most stimulating contributors. All who knew him must grieve over the death of this princely man.

He was born in Japan in 1881, and almost constantly from 1914, when he became Assistant Curator of Oriental Art at the University of Pennsylvania Museum, he devoted his great intellectual energies to the study and analysis of the civilizations of Eastern Asia. Three times he conducted expeditions in China: once for the University Museum (1915-17), and twice for the Freer Gallery of Art (1923-27, and 1929-34). During the last war he served as Assistant U. S. Naval Attaché in China (1918-20). In (1921-22) he studied and gave instruction in archaeology at Columbia University. From 1922 until his death on June 16, 1942 he was Associate Curator, and Associate in Archaeology at the Freer Gallery of Art in Washington, D. C.

Endowed with a fabulous memory, C. W. Bishop acquired an encyclopedic knowledge of man's culture. With keen analytic ability, rare powers of generalization, and a happy clarity of expression, he was able to extract from this storehouse the essential facts about man's early history and to present them in ordered and highly engaging fashion. His book Man from the farthest past is a superb example of elucidation and the best sort of popularization of prehistory. Two themes inspired much of his study and writing: the uniformity of elements on which early civilizations were built; and, the cultural debt owed by the Far East to the older centers of civilization in the Near East. These themes are clearly set forth in a booklet published the week before his death, Origin of the far eastern civilizations: $A$ brief handbook (the first in the Smithsonian Institution's "War background studies"). He had the faculty of broadening the perspective on any subject about which he wrote, whether it was the vexed problem of early Chinese chronology, the place of geography in the development of an early culture, or the diffusion of some social or material technique. Not many details of his archaeological work in China are in print aside from his observations on the Hsin-cheng finds-a classic in the field where information is most scanty-and the workmanlike report of his excavation of a disappointingly meager Western Han site. It is all the more difficult to understand why his eagerly awaited report, Archaeological researches in China 1923-1934, although completed, should have been witheld from publication. 
C. W. Bishop had countless friends. He was kindly, modest, and witty, and generous almost to a fault. Always eager to help younger scholars, he shared freely the knowledge he had acquired through years of study and travel, aided them with their manuscripts, and helped them to become established in their professional fields. Although all who knew him will miss the stimulation of his mind and the warmth of his friendship, death will not end the humanizing influence he brought to studies in the Far Eastern field.

C. Martin Wilbur

\section{BIBLIOGRAPHY OF PUBLICATIONS}

1914-1942

1914

"A masamune blade," Muserm joumal, Phila., 5, 206-12.

"Tibetan sacred art illustrated by two Tibetan paintings in the museum," Ibid., 5, 189-205.

1916

"The expedition to the Far East," Ibid., 7, 97-118.

"Notes on Chinese statuary," Ibid., 7, 152-77.

"Two early Chinese Buddhist sculptures," Ibid., 7, 245-63.

1917

"The Chinese expedition," Ibid., 8, 197-201.

"China's part in the war," Journal of race development, 9, 56-70.

"The horses of T'ang T'ai-tsung," Museum journal, 9, 244-72.

"Recent acquisitions of Chinese sculpture," lbid., 9, $123-47$.

"Two Chinese bronze vessels," Ibid., 9, 99-120.

1921

"The elephant and its ivory in ancient China," Journal of the American Oriental society, 41, 290-306. "Shantung, China's Holy Land," Museum journal, 12, 85-115.

"The geographical factor in the development of the Chinese civilization," Geographical review, 12, $19-41$.

Review of M. C. Burkitt: Prehistory: a study of early cultures in Europe and the Mediterranean basin, Ibid., 12, 320-21.

Review of Berthold Laufer: Sino-Iranica: Chinese contributions to the history of civilization in ancient Iran, Ibid., 12, 662-64.

Review of Aurel Stein: Serindia: detailed report of explorations in contral Asia and westernmost China, vol. 1, lbid., 12, 660-62.

Review of J. M. Tyler: The New Stone Age in northern Europe, Ibid., 12, 322-23.

"The historical geography of early Japan," Ibid., 13, 40-63. Reprinted in Smithsonian annual report for 1925, 547-68.

"The bronzes of Hsin Cheng hsien," Chinese social and political review, 8, 81-99. Reprinted in Smithsonian annual report for 1926, 457-68. 
"The ritual bullfight," China journal of science and arts, 3, 630-37. Reprinted in Smithsonian annual report for 1926, 447-56.

1926

"The problem of the Min River caves," Chinese social and political science review, 10, 46-61.

"The origin of the Chinese civilization," Henri Maspero. Translated. Smithsonian annual repont, 433-52.

"Archaeological expedition to China," Explorations and field-work of the Smithsonian Institution in 1927, 109-18.

"The find at Hsin Cheng hsien," Artibus Asiae, 110-21.

"Notes on the tomb of Ho Ch'u-ping," lbid., 34-46.

"Our opportunity in China," National republic, 16, 30-31 and 37.

Review of L. H. Dudley Buxton: The peoples of Asia, Geographical review, 18, 169-71.

Review of Harold Lamb: Genghis Khan: the emperor of all men, lbid., 18, 699-700.

Review of S. W. Shirokogoroff: Anthropology of northem China, Ibid., 18, 343-44.

1929

"Archacological field-work in China," Explorations and field-work of the Smithsonian Institution in $1928,133-40$.

Review of Jules Sion: Asie des moussons, Geographical review, 19, 514-16.

1930

Man from the farthest past, New York, Smithsonian scientific series. Second printing (chapter added) 1938.

1932

Excavation of a west Han dynasty site at Yen-tzu Ko-ta, Wan Ch'uan hsien, southwestern Shansi, Shanghai, Kelley and Walsh. 72 pp.

"China, aesthetic development," Enc. Britannica, 14th edition, 546-49.

"The chronology of ancient China," Journal of the American Oriental society, 52, 232-47.

"The rise of civilization in China with reference to its geographical aspects," Geographical review, $22,617-31$.

"The worship of earth in ancient China," Reprinted from Excavation of a west Han dynasty site, in Journal of the north-China branch of the royal Asiatic society, 44, 24-43.

"The neolithic age in northern China," Antiquity, 7, 389-404.

"Rhinoceros and wild ox in ancient China," China journal, 18, 322-30.

1934

"The beginnings of north and south in China," Pacific affairs, 7, 297-325.

Review of V. Gordon Childe: New light on the most ancient East, Ibid., 7, 474-76.

Review of Kenneth Scott Latourette: The Chinese: their history and culture, Geographical review, 24, 686-87.

Review of Harold Peake and Herbert John Fleure, Jr.: The horse and the sword, Pacific affairs, 7, 478-79.

Review of René Grousset: The civilizations of the East, American journal of archacology, 39, 434-35. Review of Eleanor Holgate Lattimore: Turkestan reunion, Geographical review, 25, 350-51.

Review of Owen Latrimore: Mongols of Manchuria, Ibid., 25, 349.

Review of Mary A. Nourse: The four hundred milliom, Chims magazine, April, p. i9. 
1936

"A civilization by osmosis-ancient China," American Scholar, 5, 323-28.

"Origin and early diffusion of the traction plow," Antiquity, 10, 261-81.

Review of Mrs. Dagney Carter: China magnificent: five thousand years of Chinese art, Pucific affairs, 9, 112-14.

1937

"Early Chinese cultures and their development: a new working hypothesis," by Wolfram Eberhard. Translated. Smithsonian anmual report for 1937, 513-30.

Review of Albert Hermann: Historical and commercial atlas of China, Geographical review, 27, 515-17.

Introduction for Herrlee G. Creel: The birth of China, 7-9.

"An ancient Chinese capital: carthworks at old Ch'ang-an," Antiquity, 12, 68-78. Reprinted in Smithsonian annual report for 1938, 569-78.

"Long-houses and dragon-boats," Ibid., 12, 411-24.

"The beginnings of civilization in eastern Asia," Journal American Oriental society, Supplement, 45-61. Reprinted in Antiquity, 14, 301-16. Smithsonian annual report for 1940, 431-46.

Review of Derk Bodde: China's first unifier: a study of the Ch'in dynasty as seen in the life of $L i S s u$, Pacific affairs, 12, 87-90.

Review of Albert Hermann: Das land der seide und Tibet in lichte der antike, Geographical review, 29, 693-95.

Review of Geoge Montandon: La civilisation Ainou et les cultures arctiques, Ibid., 167-68.

Review of G. D. Wu: Prehistoric pottery in China, Antiquity, 13, 478-81.

"A synopsis of the development of civilization in eastern Asia," mimeographed leaflet, Washington.

1940

Review of Sven Hedin: The silk road, Geographical review, 30, 515-16.

Review of Wm. M. McGovern: The early empires of central Asia: a study of the Scythians and the Huns and the part played in world history, Pacific affairs, 13, 359-62.

1941

"Archaeclogical researches in China, 1923-1934," mimeographed leaflet, Washington.

1942

Origin of the Far Eastern civilizations: a brief handbook, Smithsonian institurion, War background studies, no. $1.53 \mathrm{pp}$. 